\title{
THE ROLE OF GERMANY IN THE TRANSNISTRIA CONFLICT
}

\section{HISTORIC BACKGROUND}

The territory of Transnistria is a special enclave on the left bank of the Dniester River, with cultural and historical traditions markedly different than those in neighboring Moldova. The Ottoman conquests, followed by the partitioning of Poland, made the Dniester a river marking the border between the Russian and Turkish empires. When Turkey grew weaker in the international arena and Russia grew stronger after its victory over Napoleon, the territory - known as Bessarabia - fell under Russian rule until 1918, to be embraced by Greater Romania after the collapse of tsarism (LubiczMiszewski, 2012: 121-122).

After the Soviet Union was formally established in 1922, the Moscow government immediately began to question the legality of Bessarabia's inclusion within Romania and never accepted this annexation. In 1924, the Moldovan Autonomous Socialist Soviet Republic (MASSR) was established on the left bank of the Dniester as an integral part of the Ukrainian Socialist Soviet Republic.

Before World War II, Germany showed no interest in this region of Europe, believing that this territory was a zone of influence of its ally, the Austro-Hungarian monarchy, and then of the Soviet Union. In the interwar period, Romania was a member of the French system of eastern alliances (Little Entente) and Berlin, which supported Hungarian revisionist sentiments, held no esteem for Bucharest whatsoever. At the time of the Weimar Republic, Romania became interested in German capital and obtaining a loan from the Wolff concern to develop their railroads, but Germany shunned any binding declarations (Koszel, 1987: 64).

The situation changed when the National Socialists came to power in Germany and launched an extensive armaments program. Romanian oil fields and agricultural products became a focal point for the Third Reich. Skillfully fueling Hungarian claims to Transylvania, Germany simultaneously indicated that it was ready to contain them in return for far-reaching economic concessions from Romania. On March 23, 1939, Romania signed a humiliating trade agreement with Germany, whereby the economy of Romania was subjugated to German needs. Nearly the entire exports of Romanian crude oil and cereals would go to Germany (Akten, 1961-1963: 76-80).

In the Ribbentrop-Molotov Pact, signed on August 23, 1939, the Soviet party stressed its interest in Bessarabia while Germany expressed its "utter disinterest" in this territory. After the fall of France on June 26, 1940, as a result of an ultimatum is- 
sued by Moscow, Bessarabia was passed to the USSR, alongside the area of Bukovina, which was inhabited by the Ukrainian population (Kastory, 2002).

As expected by the Soviet Union, Germany did not comment on this situation. However, the strengthening of the USSR was certainly against Hitler's wishes. Sentiments in Berlin were accurately reflected by Nazi minister of propaganda, Joseph Goebbels, who wrote in his diary on June 29, 1940: "Yesterday, Romania succumbed to Moscow. Bessarabia and North Bukovina are being transferred to Russia. For us, this is anything but pleasure. The Russians are taking advantage of the situation [...] Under pressure from Moscow, Romania unconditionally capitulated" (Goebbels, 2013: 88).

The disgrace of Romania, which collaborated with Germany and fought the Soviet Union, resulted in the reinstatement of the borders from before 1941 once the hostilities ended, and the territories annexed by the Soviet Union were not returned to Romania (Darski, 1994: 189). With time, the Moldovan SSR became an agricultural hub in the Soviet Union. Its right bank was famous for vineyards, vegetables and fruit, while heavy industry was located mainly on the left bank of the Dniester. The area was highly urbanized and infrastructure was well-developed, containing approximately 65 per cent of Moldovan heavy industry, 80 per cent of its energy potential and a strong armaments sector (Solak, 2014: 19).

Romanian-Moldovan relations intensified after communist dictator Nicolae Ceauşescu was toppled in December 1989 and in response to the symptoms of the decomposition of the Soviet empire. The political platforms of nationalist parties began to talk about the unification of Moldova with its homeland, and constructing a federation. Bucharest and Chisinau carefully watched the beginning of negotiations on German reunification, which they saw as analogous to their own situation and a model to follow.

The trend to integrate into Romania exacerbated the tensions and national conflicts on the left bank of the Dniester. The political platform presented by the Popular Front of Moldova featured strong nationalistic sentiments, which strongly mobilized the Russian-speaking populations from Transnistria and Gaugazia to support the postulates of a bilingual Moldova first, then its autonomy and, eventually, the independence of Transnistria. The Russians living in Moldova, Russian-speaking Moldovans and Ukrainians rebelled. The conflict was additionally fueled by the specific character of the elite in Soviet Transnistria, who originated primarily from the military and the management boards of the industrial plants located there. The cadres, imported from the Russian Soviet Federative Socialist Republic and Ukrainian Soviet Socialist Republic, entirely identified with Moscow and did not want to succumb to the Moldovan nationalists (Oleksy, 2013). In December 1990, in Rybnitsa and Tiraspol a referendum on the formation of the Transnistrian Autonomous Socialist Republic was held and won over 90 per cent of votes. The leaders of Transnistria concluded that an agreement with the Moldovans was unfeasible and, on November 5, 1990, the Pridnestrovian Moldavian Republic (PMR) was eventually established. It was headed by Igor Smirnov, who served as the president of Transnistria from December 1991. On December 8, 1991, the Supreme Council unilaterally declared the sovereignty of Transnistria. This was preceded by Moldova declaring independence on August 27, as the last post-Soviet republic to do so (Büscher, 1996: 90-98; Oleksy, 2016). 


\section{THE ESCALATION OF THE CONFLICT AND THE GERMAN RESPONSE}

The government in Chisinau did not acknowledge the formation of the PMR and set out to restore the territorial integrity of the country by force. The military operations undertaken by the weak and poorly organized Moldovan troops were limited to several months of fighting for Dubosary in March 1992 and for Bendery in June 1992. Moldovan soldiers fought without conviction, the conscription was boycotted by Moldovan Ukrainians and Russians, and even those with patriotic zest thought that the lands on the other bank of the Dniester had nothing to do with the idea of Greater Romania (Oleksy, 2013: 169-170).

Moldovan troops failed to make progress on any section of the front, since they encountered fierce resistance from Transnistrian guards and volunteers, including numerous Cossacks. The situation was finally resolved when the separatists were joined by the regular troops of the Russian 14th Army under the command of General Alexandr Lebed. After the USSR disintegrated, for prestigious and specific economic reasons, Russia could not accept further depletion of its territories and allow Moldova to drift towards European structures (Malek, 2006: 10). Due to direct pressure from the president of the Russian Federation, Boris Yeltsin, on July 6, 1992, Moldovan president Mircea Snegur signed an agreement on the principles of the peaceful resolution of the conflict. Between 7 and 18 July, the fighting subsided. The number of fatalities on both sides was estimated at around 1,000 people (Dima, 1999: 37-64).

In 1990-1992, the issues of Moldova and Transnistria were at the very bottom of the list of German priorities. The government of Helmut Kohl faced the primary task of successful completion of the reunification of two German states, a process carried out both internally and via direct negotiations with the USRR, the USA, France and the United Kingdom, within the 2+4 negotiation framework. After the reunification of Germany, the ruling CDU/CSU-FDP coalition focused on achieving genuine progress in the process of European integration and building the European Union. The Soviet Union was falling apart at that time, raising considerable concerns with its unpredictability. Germany wanted the Soviet empire to be dismantled without bloodshed and the Soviet troops stationed in the former East Germany to be withdrawn as soon as possible. States of the former Eastern Bloc were at the stage of profound political and economic transformation, and needed support to this end. The situation in Yugoslavia was exacerbated when Slovenia and Croatia left the structures of the Yugoslav Federation on June 25, 1991. Being aware of the threats that the explosion of "the Balkan cauldron" could bring to South-Eastern Europe, Germany committed itself to resolving this conflict by political means, something the seasoned diplomat, Minister of Foreign Affairs Hans-Dietrich Genscher engrossed himself in (Genscher, 1995).

In this situation, Moldovan attempts to renounce Russian influences and the initial steps taken to integrate into Romania did not stir greater emotions in Germany. However, German diplomacy attached considerable importance to developing good relations with Romania, where the German minority was quite numerous. The two countries signed a Treaty on Friendly Relations and Partnership in Europe on April 21, 1992, whereby, in return for the protection of the German minority in Romania, Germany undertook to support Romania in introducing a market economy and in facilitat- 
ing an association agreement with the newly established European Union ("EuropaArchiv", 1992: D 395-402).

Given the multitude of other, more important and more dramatic events in the Balkans, the surging Moldova-Transnistria conflict was practically absent from the German media. If opinion-forming newspapers published any news on the escalation of this conflict in the first place, they would consist only of several sentences on page four or five. Even the diplomatic recognition of the Republic of Moldova by Germany on April 30, 1992, received only very modest coverage. In March 1995, the Moldovan Embassy was opened in Bonn (it was transferred to Berlin in 1998). It was not until 1996 that the first ambassador of Germany, Irene Kolhaas, presented her credentials to the Moldovan president Mircea Snegur (Deutsche Botschaft, 2020).

The interest of the German media in the problems of Transnistria rose only temporarily when General Lebed's troops of the Russian 14th Army intervened (Rußlanddroht, 1992), but the situation soon went back to normal. Chancellor Kohl wrote in his Memoirs that when President Boris Yeltsin visited Germany in mid-December 1992 to sign a German-Russian pact, he expressed his satisfaction with settling the problems related to Moldova, Georgia and South Ossetia (Kohl, 2007: 513).

After the hostilities ended, Transnistria formally remained a self-proclaimed independent republic that was not recognized by any state. It became a region of "frozen conflict" and as such joined Nagorno-Karabakh, Abkhazia and South Ossetia. Transnistria could operate only thanks to support from Russia which was viewed as the guarantor of Transnistrian independence and maintaining a modest standard of living. A unification with poor, backwards and economically fragile Moldova was out of the question. In a referendum of September 17, 2006, 97.2 percent of the public were for an independent PMR and only 3.3 per cent opted for integration into Moldova (Solak, 2014: 57).

The USA and the EU, including Germany, refused to acknowledge the referendum results, as did the Organization for Security and Cooperation in Europe (OSCE) whose observers had taken an informal part in the referendum. The head of the OSCE mission, German diplomat Claus Neukirch sought a special status to be created for Transnistria, and the stability and independence of Moldova to be supported. He believed that these conditions had not been met. Tiraspol ran an aggressive and unilateral propaganda campaign against Moldova and the questions asked in the referendum (whether one was in favor of full independence and joining the Russian Federation) did not meet the criteria of objectivity and reliability (Freie Willensbildung, 2006).

Relations with the Russian Federation were a priority for Germany, which did not hesitate to accept Moscow as the leading mediator in the conflict. In October 1994, Moldovan Prime Minister Andre Sangheli and Russian Prime Minister Vladimir Chernomyrdin signed an agreement to withdraw Russian military troops from Transnistria, which never happened. In November 1999, at the OSCE Summit in Istanbul, under international pressure Moscow reiterated its declaration to withdraw Russian troops from Transnistria by 2002, with the same result as before.

The Kremlin administration put forward its own proposals to resolve the conflict, announcing Primakov's memorandum in 1997 and Kozak's plan in 2003. According to the concept designed by the Minister of Foreign Affairs Yevgeny Primakov, Moldova 
and Transnistria should build mutual relations within the framework of a "joint state" identified by the borders of the Moldovan Socialist Soviet Republic of January 1990. Another proposal, put forward by Russian negotiator Dmitry Kozak, provided for the change of the Moldovan constitution and the transformation of the state into a federation with the autonomous entities of Transnistria and Gaugazia. This plan was clearly in favor of Transnistria and was rejected by Moldovan president Vladimir Voronin under pressure from the West. The decisive opinion was issued by the OSCE mission in Chisinau which warned that approving this plan might be detrimental to the integration of Moldova into Europe. The special US representative did not hide his disapproval of the plan, either (Neukirch, 2006: 154).

In 2004, the OSCE mission continued to negotiate with the representatives of the authorities in Transnistria, Moldova, Russia and Ukraine. Following OSCE recommendations, the Moldovan government was in favor of forming a constitutional federation with the rebellious province, but Tiraspol opted for a confederation. Quite frequent meetings held by experts and advisors were concluded in June 2004, when Transnistria representatives unexpectedly withdrew from the negotiations.

When the tension between Moldova and Transnistria intensified, the problems of this region were addressed by German deputies to the Bundestag. On May 5, 2004, the deputies from the SPD, CDU/CSU, the Green and FDP drafted a resolution which was unanimously adopted on the following day, where they supported the state unity of Moldova and the democratic transformations. On one hand, the EU was called to offer a more extensive and multifaceted economic, financial and advisory support for Moldova under the European Neighbourhood Policy, and on the other the OSCE was encouraged to persistently seek a resolution to the Transnistria conflict. Moscow was demanded to keep its earlier promises and withdraw its troops from Transnistria (Den Wegzur Einheit, 2005).

Solving the problems of Transnistria turned out to be more complicated when the leader of the Moldovan Communist Party, the above-mentioned Vladimir Voronin, assumed power as the president elected by parliament in April 2001. Accused of authoritarian tendencies, in foreign policy he tried to skillfully maneuver between the East and West. He counted on economic and financial assistance from the EU and the USA. However, his attempts to get closer to the EU and the USA met with violent reactions from Moscow: in 2005, it imposed an embargo on Moldovan agricultural products, and in March 2006 - on Moldovan wines, which were traditionally very popular in Russia. The Moldovan economy was severely weakened when the price of Russian gas supplied to the republic doubled (Rodkiewicz, 2009).

The Russian sanctions were apparently effective. President Voronin abandoned his attempts to resolve the Transnistria conflict, which he had undertaken in collaboration with Ukrainian president Viktor Yushchenko, turning to the EU, OSCE and the USA. He began probing Moscow to resolve the conflict through direct talks with the administration of President Vladimir Putin. In 2006, Russia began behind-the-scenes negotiations within a $2+1$ format (Moldova, Transnistria and Russia) seeking to eliminate Western intermediaries and weaken the negotiation position of Moldova (Chiveri, 2012).

In these conditions, difficult for Moldova, President Voronin paid a working visit to Berlin in May 2006. He talked to Chancellor Merkel about the possibilities for bilateral 
cooperation and the EU's involvement in resolving the Transnistria conflict. One year before, in May 2005, German vice-minister of economic cooperation and development visited Chisinau to talk to the government representatives there. These talks resulted in Germany allocating EUR 4 million for financial cooperation and an additional EUR 1 million for technical cooperation. These resources were to finance the development of the financial sector and agriculture (Antwort der Bundesregierung, 2007).

\section{GERMANY'S SUPPORT FOR THE ACTIVITY OF THE EU AND OSCE}

Following the dismantling of the Soviet Union, Germany sought stability for the states of the former Eastern bloc. To this end, Germany took an active part in forming the European Neighbourhood Policy (ENP) and promoted Partnership and Cooperation Agreements (PAC) with the countries from this region. On November 28, 1994, Moldova signed a PAC for a period of ten years (it entered into force on July 1, 1998). Moldova was to be supported in its efforts to democratize and to introduce a market economy (Umowa, 2004).

The EU unanimously supported Moldova in the Transnistria dispute, and Germany did not hesitate to support EU demands to withdraw Russian troops from Transnistria, and the ban on visas for the authorities of the separatist republic to enter EU territory in 2003. On the other hand, given the importance of bilateral German-Russian ties, the governments of Gerhard Schröder and Angela Merkel believed the OSCE should be the primary mediator and the best platform to consult the Russian government. From 2005, the negotiations were held in an extended 5+2 format (Moldova, Transnistria, Russia, Ukraine and OSCE), with the EU and USA invited as observers. The abovementioned Russian counter-action and commencing informal talks in the $2+1$ formula (Moldova, Transnistria and Russia) brought about a standstill in the negotiations which lasted as long as five years.

The lack of progress in resolving the Transnistria crisis resulted in yet another discussion in the Bundestag, in July 2007. Replying to an interpellation from FDP deputies, German government representatives stated that, in line with the 1999 OSCE agreement from Istanbul, Germany repeatedly demanded Russian troops be withdrawn from Transnistria, while opting for a dialog with Russia on this matter. The German government's assessment of the mediatory efforts of the OSCE was positive, as of the activities conducted by the European Union Border Assistance Mission to Moldova and Ukraine (EUBAM). The German government emphasized that it did not recognize the Community for Democracy and Rights of Nations established by the parties to the frozen conflict - Abkhazia, Nagorno-Karabakh Republic, Transnistria and South Ossetia, and promised to support ENP instruments that would attract Moldova to European structures while assisting in the resolution of the Transnistria conflict. At the same time, it announced it would continue to tightly monitor financial transactions between Germany and Transnistria (Antwort der Bundesregierung, 2007).

After the parliamentary election in August 2009, power in Moldova was assumed by a pro-West coalition opting for close cooperation with the EU. President Voronin stepped down one month later. The leaders of the Alliance for European Integration 
- Vlad Filat from the Liberal Democratic Party, Prime Minister of Moldova in 20092013, and the leader of the Democratic Party, Vlad Plahotniuc, oligarch and vicepresident of parliament in 2010-2013 - announced far-reaching pro-European reforms (Całus, 2016).

\section{MESEBERG MEMORANDUM}

German hopes for a long-lasting agreement on Transnistria were associated with the election of a young technocrat, Dmitry Medvedev as president of the Russian Federation in 2008. After the 2008 Georgian-Russian war, Berlin opted for Germany and the EU ensuring larger development support for Eastern Europe, and approved the Polish-Swedish Eastern Partnership (EP) initiative. Seeking stability for the region, Berlin openly indicated, however, that the EP, which included Moldova, should not be directed against Russia or constitute the first stage of Eastern European countries' accession to the EU, competing with the EU-Russia Partnership for Modernization (PfM) that Germany preferred (Meister, May, 2009).

At an informal meeting of Chancellor Merkel and President Medvedev held in Meseberg Castle in Brandenburg on June 4-5, 2010, the German leader suggested the involvement of both countries in resolving the issue of Transnistria in the interest of European security. Initially, a federate structure was to be established, where the separatists would be granted 5-15 per cent of parliamentary mandates in advance. This proposal aroused considerable concerns from the beginning, because the votes of Transnistrian deputies combined with Moldovan communists would make it possible to form a pro-Russian parliamentary majority and a government that would opt for tight collaboration with Moscow.

Germany playing along with Russia in Transnistria confused the EU, whose consternation was further increased by a joint German-Russian memorandum suggesting that an EU-Russia Political and Security Committee be formed. The Committee would be composed of the ministers of foreign affairs in EU states and in Russia (Sergey Lavrov) alongside the High Representative for Common Foreign and Security Policy (Catherine Ashton). This group would develop the principles of civil and military "conflict management measures" in Europe (Koszel, 2017).

In order to test the potential for EU-Russian security cooperation, the memorandum provided for joint activities "towards a resolution of the Transnistria conflict with a view to achieve tangible progress within the established 5+2 format" (Memorandum, 2010). This was an attempt at including Russia in the stabilization process in this region and granting considerable importance to cooperation with Russia. The powers of this EU-Russia Committee would be much greater than those of the NATO-Russia Council. It would establish an EU-Russian policy coordination mechanism that did not exist between the EU and the USA or even NATO. On October 18-19, 2010, the Russian, German and French leaders held the first trilateral meeting since 2006 in Deauville, France. In a joint statement they stressed their intention to enhance the strategic EU-Russia partnership and make progress towards a solution of the "frozen" Transnistria conflict (Statement, 2010). 
On September 7-9, 2011, the representatives of the "5" (Russia, Ukraine and OSCE, and the USA and EU as observers) and "2" (Transnistria and Moldova) met informally in Bad Reichenhall, Bavaria, to set the procedure for further negotiations. Germany considered the meeting a success. Visiting the USA two weeks later, German Minister of Foreign Affairs Guido Westerwelle stated that this marked the end of the deadlock and offered good prospects for the future (Außenminister Westerwelle, 2011).

According to the adopted agenda, the first " $5+2$ " meeting of a more formal nature was held in Vilnius on October 30-December 1, 2011, as had been agreed in Meseberg. The German government expected a lot from the next meeting, scheduled for February 2012 in Dublin.

In the end of 2011, Bundestag deputies were presented the general tenets of the German government's strategy in a report by AuswärtigesAmt (Federal Foreign Office). The strategy boiled down to two issues: building an atmosphere of trust between the governments in Chisinau and Tiraspol and including Russia in solving the Transnistria conflict. It was reiterated that the German government unwaveringly (Ger. unverändert) called on the Russian Federation to withdraw all military troops that were not part of the peace contingent and their equipment from Transnistria, and that inspectors from Germany and NATO states were ready to supervise this process at any moment (Antwort der Bundesregierung, 2011).

The symptoms of the thaw were also due to the election of NicolaeTimofti, supported by the ruling Alliance for European Integration, as president of Moldova in March 2012, which brought a protracted internal crisis to the end. Changes occurred also in Transnistria where Igor Smirnov was unexpectedly deposed after twenty years in power. The new president of the Pridnestrovian Moldovan Republic, Yevgeny Shevchuk, opted for the improvement of relations with Moldova in his campaign and declared that he would take steps towards the international recognition of the separatist republic and establish strategic cooperation with Russia.

Recognizing these positive developments, on June 20, 2012, through the Federal Foreign Office, Germany invited representatives of Moldova and Transnistria for confidential talks to Rottach-Egern, Bavaria. Manfred Grund, Bundestag deputy from the $\mathrm{CDU}$ and the chairman of the board of the German-Moldavian Forum, insisted on it. However, the talks had no bearing on the progress on the future of Transnistria whatsoever (Deutschlands, 2012).

Apart from publicity, the first visit of German Chancellor in Chisinau on August 22, 2012 also had little impact. The visit was supposed to solidify the pro-European attitude of Moldova. Prime Minister Vlad Filat and President NicolaeTimofti were praised by Merkel for the exemplary implementation of the Eastern Partnership principles (Bundeskanzlerin Merkel, 2012).

Much to Germany's disappointment, Russia soon turned out to have done very little to help in resolving the conflict in 2012, other than expressing consent for the formal resumption of the 5+2 talks. Appointing the eccentric and conflict-seeking Dmitry Rogozin (a former ambassador to NATO) as Russia's special envoy to Transnistria was a signal that Moscow was not interested in genuine progress. It was not until 2014 that, in connection with the events in Ukraine, Russia unexpectedly began to demand the $5+2$ talks be accelerated. Russia believed that their outcome 
should involve Transnistria being granted a special status within a united, sovereign and neutral Moldova.

The re-election of Vladimir Putin as the president of the Russian Federation in 2012 and the strengthening of his authoritarian rule somewhat confused the political elite in Germany. The consensus, whereby the democratization and integration of Russia into Europe were key to the security of the continent, was shattered. Germany began to run out of ideas how to deal with this new, increasingly undemocratic Russia. JochenFranzke wrote that a dilemma aroused as to whether to apply the "Westphalian solution," known since 1648, to Russia, or to acknowledge that there existed a direct connection between economic cooperation and international security on the one hand and respect for democratic laws and civic freedoms on the other, thereby imposing a specific model of cooperation with Russia (Franzke, 2013: 40). The coalition agreement of November 27,2013 , signed by the CDU/CSU and FDP after their victory in the parliamentary election shed light on the matter. The agreement featured an exceptionally extensive offer for Russia, encapsulated in the title Open dialog and enhanced cooperation. The agreement made a point of emphasizing that "it is in the German and European interest for Russia to be a modern and democratic state with a strong economy," because Russia was the EU's most important partner (Deutschlands Zukunft Gestalten, 2013).

\section{IN THE SHADOW OF THE EVENTS IN UKRAINE}

Transnistria was a part of Soviet Ukraine until 1940. After it gained independence in 1991, many politicians believed that its reunification with the "motherland" was something desirable, albeit unattainable, given the enormous difficulties in other areas. The 2010 presidential election was won by Victor Yanukovych, a supporter of Russia. Initially, he moved cautiously, trying to charm Moscow and Brussels alike, and he aroused the hopes of the Transnistrian separatists about the opening of the border with Ukraine. This did not happen, however, and the mandate of the EUBAM mission was extended until 2015.

At the Third Eastern Partnership Summit held in Vilnius on October 28-29, 2013, the Association Agreements with Moldova and Georgia were approved, along with the Agreements on Deep and Comprehensive Free Trade Areas (DCFTA). The agenda adopted then provided for the AA/DCFTA with Moldova and Georgia to be quickly signed and implemented; and for the liberalization of visa regimes in all partnership members and development of sectoral cooperation (Sadowski, 2013).

After President Yanukovych failed to sign the Association Agreement he was toppled and the pro-European policy in Ukraine was reinstated. Moscow responded to Ukrainian attempts to become independent by annexing Crimea on March 18, 2014, following a hastily conducted referendum (March 16). The EU and the USA retaliated by imposing economic sanctions on the Russian Federation, suspending it as a G-8 member and banning prominent Kremlin officials from entering EU territory. Chancellor Angela Merkel unambiguously condemned the annexation of Crimea, and the EU decided to accelerate the signing of Association Agreements with Georgia and Moldova (Rada Europejska 20-21 marca 2014). 
The prospect of Moldova signing the Association Agreement with the EU exacerbated the tensions between Chisinau, Tiraspol and Moscow. The parliament of the separatist territory requested Russian deputies to provide for the possibility of the incorporation of Transnistria into the Russian Federation when amending the regulations after the annexation of Crimea. However, Russia decided not to escalate the tension and did not address this issue. Simultaneously, the Russian media launched a propaganda campaign aiming to discourage Moldova from rapprochement with the EU (Schmidt, 2014).

In this situation, Germany decided to spare no effort to prevent the Crimean scenario from repeating in Moldova. The prospect that the Russian soldiers stationed in Transnistria could be used as "peace corps" and the organizations of pro-Russian separatists in Gaugazia could trigger a destabilization process in Moldova questioned the future of the Eastern Partnership. Under these circumstances, an exaggerated assumption was made that, after nearly four years, Moldova was the first EP member to have fulfilled all the requirements for visa-free movement. This was confirmed by German Minister of Foreign Affairs Frank-Walter Steinmeier, who visited Chisinau on April 23, 2014, and - working alongside his French counterpart, Laurent Fabius - sought to stabilize the situation in the region after the annexation of Crimea and demonstrate that the EU was united with a reforming Moldova (Steinmeier und Fabius, 2014).

As promised, on April 28, 2014, visas for Moldovans travelling to EU states (for up to ninety days) were lifted. What was more important, however, was that Association Agreements with Ukraine, Georgia and Moldova were simultaneously signed on June 27, 2014 (Uklad o stowarzyszeniu, 2014).

The Fourth Eastern Partnership Summit in Riga (May 21-22, 2015) left no illusions as to their future membership of the EU. Before the summit, Russia warned that the former Soviet republics should not have to choose between either Russia or the European Union. Despite the support from Sweden, Poland and Baltic states, the majority of EU states opted for Merkel, who - before going to Riga - had said in the Bundestag that the Eastern Partnership was not an instrument of facilitating EU enlargement, but rather of the rapprochement of EP members and the EU (Joint Declaration, 2015).

\section{STATUS QUO PERPETUATED}

After 2015, Moldova was most influenced by oligarch Vlad Plahotniuc, chairman of the ruling Democratic Party, who as a matter of fact collaborated with the proRussian Party of Socialists, actually blocking pro-European reforms and oligarchizing the political system. The internal weakness and frequent government reshuffling in Moldova suited Russia, which could not come to terms with the fact that Chisinau had signed the Association Agreement. The propaganda campaign in Russian media intensified, as did the attempts to internally destabilize Moldova (Chisinau, 2016).

In 2016, Germany took over OSCE chairmanship and declared its greater commitment to resolving the Transnistria conflict. Minister Steinmeier, acting in the capacity of the OSCE Chair, appointed seasoned German diplomat, Cord Meier-Klodt (later German ambassador in Bucharest) as Special Representative for the Transnistrian Set- 
tlement Process. Of the five rounds of talks planned, only two were held in 2014. Tensions between the two key negotiators, Russia and Ukraine, alongside the weak OSCE mechanisms operating in Eastern Ukraine discouraged further talks in 2015. It was not until June 3, 2016, that minister Steinmeier managed to resume the 5+2 talks in Berlin. He was not very successful, however, as neither of the parties to the conflict sought to end the stalemate. In this situation, signing a technical protocol was deemed satisfactory (Transnistrien, 2016).

The first direct presidential election in Moldova in November 2016 was won by Igor Dodon, from the Party of Socialists of the Republic of Moldova, who never hid his pro-Russian sentiments. He ruled out any attempts at rapprochement between Moldova and NATO. His anti-Western attitude and aversion to the EU were to lay the foundations for the strategic Russian-Moldovan alliance (Miarka, 2018: 132).

The final declaration from the Fifth Eastern Partnership Summit in Brussels on November 24, 2017, acknowledged the European aspirations of Ukraine, Moldova, Georgia, Armenia, Azerbaijan and Belarus, but failed to mention the European prospects any of them could potentially enjoy (Szczyt Partnerstwa Wschodniego, 2017). France, Ireland, Portugal, Spain and the Netherlands were traditionally against, and they had not even sent delegations at the highest level to the summit.

Three days later, on November 27, another round of the $5+2$ negotiations was held in Vienna. Both sides officially confirmed their previous arrangements and committed to solving other important bilateral problems in the coming months, including introducing uniform number plates (for Moldova and Transnistria), and thus allowing cars registered in the separatist region to legally travel outside Moldova (Całus, 2017).

It is clear that the presence of Russian army troops in the rebellious republic were a major threat to the process of internal stabilization in Moldova and any actual breakthrough in negotiations on reintegration with Transnistria. The troops were intended to block the pro-Western ambitions of Moldova and to control Ukraine and nearby Romania, which is a member of NATO. The Russian forces consisted of two battalions (about 1,500-1,700 soldiers) of motorized infantry, one of which (about 400 soldiers) was stationed in Transnistria as peacekeepers under the 1992 agreement. The remaining Russian soldiers were part of what was called the Operational Group of Russian Forces.

As mentioned above, Russia consistently rejected or ignored the calls to withdraw its troops from the separatist republic, including the UN resolution on this matter that was rejected once again on June 23, 2018. When a resolution on the "complete withdrawal of the foreign armed forces from the territory of the Republic of Moldova" was adopted at the OSCE Parliamentary Assembly session on July 11, 2018, the Russian delegation demonstratively left the rooms in protest (UN-Vollversammlung, 2018; Zgromadzenie Parlamentarne, 2018).

Germany supported both resolutions. An entry posted to the Federal Foreign Officewebsite states that Germany has consistently opted for giving new impetus to the negotiations between Moldova and Transnistria. The most important goal is to maintain Moldova's territorial integrity and to grant the Transnistrian region a special status. Therefore, the German government supports the actions of the OSCE as an intermediary (Vergessene Konflikte, 2018). 
The winner in the parliamentary election in Moldova on February 24, 2019, was the pro-Russian Party of Socialists (PSRM). Failing to have garnered the majority needed to form the government, the party unexpectedly entered into a coalition with the proEuropean anti-establishment bloc Acum (Now). The ruling Democratic Party (PMD) came third. The head of the new government, which was not expected to last long, was the leader of Acum - Maia Sandu (Sieg, 2019).

It would not have been possible to create this rather exotic cabinet without external intervention. On June 3, 2019, Russia's deputy prime minister and the president's representative for Moldova, Dmitry Kozak, the representative of the US Department of State for Eastern Europe, Bradley Freden, and the European Union commissioner for enlargement, Johannes Hahn, came to Chisinau. Each of them held a series of meetings with Moldovan politicians which resulted in the resumption of coalition negotiations between the pro-Russian socialists and Acum. The meetings brought about the formation of a new government and ended the omnipotence of Plahotniuc, who left the country on June 14; and the judges of the Constitutional Court who were allied to him resigned.

The new government opted for a pro-European course while maintaining good relations with Russia. The government identified fighting against corruption as its main task, and in this respect it could count on support from Brussels and Berlin. The European Commission quickly signed an agreement on financial support amounting to EUR 40 million (the first tranche of EUR 14.54 million). Germany had already pledged aid of EUR 14 million for development aid in the areas of "democracy, civil society, public service and decentralization” (Moldau: Beziehungen zu Deutschland, 2019).

On July 16, 2019, Prime Minister Maia Sandu paid a visit to Berlin. Chancellor Merkel promised to support the Moldovan reform program "with all her heart." She understood the European aspirations of Chisinau, but decided that this matter was not topical at the moment (Ich sage weder Ja noch Nein am heutigen Tag) (Reformen "aus ganzem Herzen", 2019).

Germany has supported Moldova's state and economic sovereignty on various levels. In 1991, Germany sent humanitarian convoys to the country embroiled in an armed conflict with Transnistria. Since 1992, Germany has provided a total of EUR 133 million for development aid. After Romania and Italy, Germany has become the third most important trading partner of Moldova. In 2018, Germany was fifth in Moldovan imports and third in exports. There are 400 German companies operating there, and the German government has financed post-graduate studies and management studies for around 300 young Moldovans. Thanks to the cooperation with the Federal Foreign Office, in 2007 the following German foundations began cooperation with Moldova: Volkswagen Stiftung, Gerda Henkel Stiftung, HertieStiftung, KonradAdenauer-Stiftung affiliated with the CDU and Friedrich Ebert Stiftung affiliated with the SPD. Germany has committed to supporting civil society and respect for human rights. Training for independent journalists and activists of civic movements has been organized (13. Bericht der Bundesregierung, 2018).

The new coalition, which took into account the interests of both Russia and the European Union, was perceived positively in Brussels, the USA, NATO and the IMF. However, it did not last long. The dispute over the procedure for nominating candi- 
dates for the post of general prosecutor led to the collapse of the Sandu government on November 19, 2019, after the coalition was terminated by the PRSM. The new minority government of Moldova, headed by Ion Chicu, although formally non-party, was in fact controlled by President Dodon and the PSRM. This party taking power meant that the reforms were restricted, relations with the West deteriorated, and corruption investigations were halted. The multidirectional policy declared by the government and President Dodon in pursuit of maintaining good relations with both Russia and the EU in practice increased the Kremlin's influence in Moldova (Całus, 2020a).

The activities of Germany and the EU continue to support Moldova's pro-European tack and attempt to protect it from drifting towards Russia, but this is a task doomed to failure. Being aware that they cannot count on EU membership, the citizens of Moldova and Transnistria are making the most of the current situation. Pro-European democrats and pro-Russian socialists are equally corrupt and often mutually connected by various business interests. A significant part of the political class is not seeking EU membership, as this would mean the need for reforms and greater transparency, which would harm their financial interests. Nearly half of Moldova's inhabitants are against joining NATO, knowing that this would be negatively received in Moscow, and they support the constitutional provision on neutrality (Moldawia, 2019).

Paradoxically, in 2020, Russia has become the greatest supporter of Transnistria joining with Moldova. Russia has not recognized the independence of this separatist republic, but demands that the potential reunification take place on Russian terms. In some unspecified federation, a pro-Russian Transnistria infiltrated by Russian services would co-decide on Moldova's foreign policy, which would block any attempts to integrate into NATO or the EU. Additionally, Russia would not have to send gas to Transnistria for free anymore and directly support its budget. The burden of maintaining this region would fall on the shoulders of Moldova (Całus, 2020b).

It is beyond doubt that the frozen conflict over Transnistria is not on European minds. After a short period of armed struggle in the early 1990s, it did not exacerbate international tensions or attract the attention of international public opinion. The absence of physical violence and minor economic and legal tensions have encouraged Western Europe to remain indifferent to Transnistria's problems. Germany may have seen the persistent attempts to persuade the representatives of both governments to negotiate and contributing to lowering tensions between the two conflicting parties through achieving small agreements between Chisinau and Tiraspolas its success.

\section{REFERENCES}

Akten zur Deutschen Auswärtigen Politik (1961-1963), Serie D, Frankfurt/Main.

Antwort der Bundesregierung auf die Kleine Anfrage der Abgeordneten Markus Löning, Michael Link (Heilbronn), Christian Ahrendt, weitererAbgeordneter und der Fraktion der FDP (2007), Drucksache 16/2133, Zur Situation in Transnistrien (RepublikMoldau), http://dipbt. bundestag.de/doc/btd/16/022/1602289.pdf(12.02.2020).

Antwort der Bundesregierung auf die Kleine Anfrage der Abgeordneten Viola von Cramon-Taubadel, Volker Beck (Köln), Marieluise Beck (Bremen), weitererAbgeordneter und der Fraktion 
BÜNDNIS 90 DIE GRÜNEN. Stand des Meseberg-Memorandums (2011), Deutscher Bundestag Drucksache 17/8239, http://dipbt.bundestag.de/dip21/btd/17/082/1708239.pdf (15.03.2020).

Außenminister Westerwelle begrüßt Entschluss zur Wiederaufnahme offizieller 5+2-Verhandlungen (data), AA, http://www.auswaertigesamt.de/DE/Infoservice/Presse/Meldungen/2011/110922_BM_Transnistrien_Verhandlungen.html (15.03.2020).

13. Bericht der Bundesregierung über ihre Menschenrechtspolitik Berichtszeitraum 1 Oktober 2016 bis 30. September 2018 (2018), https://www.auswaertiges-amt.de/blob/2280742/640affab 15c196941ae8a8541530155e/mrb-13-data.pdf (3.03.2020).

Bundeskanzlerin Merkel besucht die Republik Moldau, Die Bundeskanzlerin, 22.08.2012, https:// www.bundeskanzlerin.de/bkin-de/aktuelles/bundeskanzlerin-merkel-besucht-die-republikmoldau-704964 (22.02.2020).

Büscher K. (1966), Separatismus in Transnistrien - Die PMR. zwischen Russland und Moldova, "Osteuropa", No. 9.

Całus K. (2016), Państwo niedokończone. 25 lat mołdawskiej niepodległości, "Prace OSW”, No. 59, December 2016, https://www.osw.waw.pl/sites/default/files/prace_59_pl_25_lat_moldawskiejnet.pdf (16.02.2020).

Całus K. (2017), Naddniestrze wejdzie w skład Mołdawii? Kulisy porozumienia mołdawsko-naddniestrzańskiego, https://www.eastbook.eu/2017/12/07/naddniestrze-wejdzie-w-sklad-moldawii-kulisy-porozumienia-moldawsko-naddniestrzanskiego (19.02.2020).

Całus K. (2020a), Pozorna wielowektorowość. Mołdawia pod rząami socjalistów, "Komentarze OSW", No. 321/2020, https://www.osw.waw.pl/pl/publikacje/komentarze-osw/2020-02-28/ pozorna-wielowektorowosc-moldawia-pod-rzadami-socjalistow (5.04.2020).

Całus K. (2020b), Mołdawia. Państwo niekonieczne, Wołowiec.

Chisinau in der russischen Zange (2016), Deutsche Welle,1.06, https://www.dw.com/de/ chisinau-inder-russischen-zange/a-18490412 (25.03.2020).

Chiveri V. (2012), Die geopolitische Falle im Transnistrien-Konflikt, Wien, http://othes.univie.ac. at/18516/1/2012-02-11_0501125.pdf(15.03.2020).

Darski J. (1994), Rumunia. Historia, wspótczesność, konfliktynarodowe, Warszawa.

Deutschlands stille Transnistrien-Diplomatie, Deutsche Welle, 20.06.2012, https://www.dw.com/de/ deutschlands-stille-transnistrien-diplomatie/a-16037114 (16.03.2020).

Den Wegzur Einheit und Demokratisierung in der Republik Moldau unterstützen. Antrag der Fraktionen der SPD, CDU/CSU, BÜNDNIS 90/DIE GRÜNEN und FDP (2005), Deutscher Bundestag. Drucksache 15/3052, http://dipbt.bundestag.de/dip21/btd/15/030/1503052.pdf (14.02.2020).

Deutschlands Zukunft Gestalten. Koalitionsvertrag zwischen CDU, CSU und SPD (2013), https:// www.cdu.de/sites/default/files/media/dokumente/koalitionsvertrag.pdf (12.03.2020).

Dima N. (1999), The Moldavian-Dnestr Republic. A Geo-Political Game, "The Journal of Social, Political, and Economic Studies".

Deutsche Botschaft Chisinau (2020), https://chisinau.diplo.de/md-de (19.02.2020).

"Europa-Archiv", (1992), No. 10.

Franzke J. (2013), Realitätoder Mythos? Zur Strategischen Partnerschaft zwischen Deutschland und Russland, "WeltTrends", No. 89.

Freie Willensbildung in Transnistrien nicht möglich (2006), Deutsche Welle, 21.09. https:// www.dw.com/de/freie-willensbildung-in-transnistrien-nicht-m\%C3\%B6glich/a-2180593 (13.02.2020). 
Genscher H.-D. (1995), Erinnerungen, Berlin.

Goebbels J. (2013), Dzienniki, vol. 2, 1939-1943, Warszawa.

Hillgruber A. (1965) Hitler, König Carol und Marschall Antonescu. Die deutsch-rumänischen Beziehungen 1938-1944, Wiesbaden.

Joint Declaration of the Eastern Partnership Summit (Riga, 21-22 May 2015), https://www.consilium.europa.eu/media/21526/riga-declaration-220515-final.pdf (24.03.2020).

Kastory A. (2002), Rozbiór Rumunii w 1940 r., Warszawa.

Kohl H. (2007), Erinnerungen 1990-1994, München.

Koszel B. (1987), Rywalizacja niemiecko-włoska w Europie Środkowej i na Bałkanach w latach 1933-1941, Poznań.

Koszel B. (2017), Meandry polityki niemieckiej wobec Rosji w okresie rządów prezydenta Dmitrija Miedwiediewa (2008-2012), "Krakowskie Studia Międzynarodowe", No. 2.

Lubicz-Miszewski M. (2012), Geneza, przebieg i próby przezwyciężenia konfliktu o Naddniestrze, “Zeszyty Naukowe WSOWL”, No. 3.

Malek M. (2006), Der Konflikt im Dnjestr-Gebiet (Moldova). Analyse und Dokumente, Schriftenreihe der Landesverteidigungsakademie, Wien, No. 7.

Meister S., May M.-L. (2009), Die Östliche Partnerschaft der EU - ein Kooperationsangebot mit Missverständnissen, "DGAPstandpunkt", No. 7.

Memorandum. Meeting of Chancellor Angela Merkel and President Dmitri Medvedev on 4-5 June 2010 in Meseberg, https://russiaeu.ru/sites/default/files/user/files/2010-06-05-mesebergmemorandum.pdf (18.03.2020).

Miarka A. (2018), Stosunki mołdawsko-rosyjskie w drugiej dekadzie XXI wieku, "Przegląd Wschodnioeuropejski", No. 1.

Moldau: Beziehungen zu Deutschland (2019), AA, https://www.auswaertiges-amt.de/de/aussenpolitik/laender/moldau-node/-/201938 (28.02.2020).

Mołdawia: Większość obywateli przeciw przystąpieniu do NATO (2019), "Rzeczpospolita", 23.09.2019.

Neukirch C. (2006), Krisenmanagement - Wiederaufnahme des Prozesses: die OSZE-Mission in Moldau 2004/2005, “OSZE-Jahrbuch 2005”, Baden-Baden.

Oleksy P. (2013), Mołdawski nacjonalizm vs. Naddniestrzańska państwotwórczość - przesłanki spotecznej mobilizacji w konflikcie naddniestrzańskim, "SensusHistoriae", Vol. XI.

Oleksy P. (2016), Wspólnota z przypadku. Studium tożsamości mieszkańców Naddniestrza, Gniezno.

Rada Europejska 20-21 marca 2014. Konkluzje, http://www.consilium.europa.eu/uedocs/cms_data/ docs/pressdata/pl/ec/141756.pdf (13.03.2020).

Reformen “aus ganzem Herzen” unterstützen (2019), Bundeskanzlerin, 16.07, https://www.bundesregierung.de/breg-de/aktuelles/merkel-empfaengt-sandu-1648018 (29.03.2020).

Rußland droht seiner Nachbarn (1922), "Die Welt" 22.06.

Rodkiewicz W. (2009), Od demokracji ,wirtualnej” ku europejskiej: Geneza i konsekwencje przetomu politycznego w Mołdawii, "Prace OSW", December 2009, Ośrodek Studiów Wschodnich im. Marka Karpia, Warszawa, https://www.osw.waw.pl/sites/default/files/prace_32_1_0.pdf (15.02.2020).

Sadowski R., Szczyt w Wilnie: bez przełomu w Partnerstwie Wschodnim (2013), "Analizy OSW", 4.12.2013, https://www.osw.waw.pl/pl/publikacje/analizy/2013-12-04/szczyt-w-wilnie-bezprzelomu-w-partnerstwie-wschodnim (18.03.2020).

Schmidt F. (2014), Transnistrien Russlands nächster Beitrittskandidat, "Frankfurter Allgemeine Zeitung", 18.03 . 
Sieg M. (2019), Regierungsumbildung in der Republik Moldau: Formalisierung der Koalition von PSRM und PDM, https://www.kas.de/de/laenderberichte/detail/-/content/regierungsumbildung-in-der-republik-moldau-formalisierung-der-koalition-von-psrm-und-pdm (28.03.2020).

Solak J. (2014), Mołdawia: republika na trzy pęknięta. Historyczno-społeczny, militarny i geopolityczny wymiar "zamrożonego konfliktu" o Naddniestrze, Toruń.

Statement for the France-Germany-Russia Summit in Deauville (18-19 October 2010) (final), Die Bundesregierung, https://archiv.bundesregierung.de/resource/blob/656922/478604/81cb5 f72d691edace00d9e33c67c5a27/2010-10-19-erklaerung-gipfeltreffen-deauville-eng-data. pdf?download=1 (18.02.2020).

Steinmeier und Fabius besuchen Moldau und Georgien, „Die Zeit” 23.04.2014.

Szczyt Partnerstwa Wschodniego (24 listopada 2017), https://www.consilium.europa.eu/pl/eapsummit/ (29.03.2020).

Transnistrien: Von einer gemeinsamen Vision weit entfernt, "Deutsche Welle", 1.07.2016, https:// www.dw.com/de/transnistrien-von-einer-gemeinsamen-vision-weit-entfernt/a-19371025. (19.09.2019).

Układ o stowarzyszeniu między Unia Europejska i Europejska Wspólnota Energii Atomowej oraz ich państwami członkowskimi, z jednej strony, a Republika Mołdawii, z drugiej strony, Dziennik Urzędowy Unii Europejskiej L 260/4, https://eur-lex.europa.eu/legal-content/PL/TXT/ HTML/?uri=CELEX:22014A0830(01)\&from=PL (22.03.2020).

Umowa o partnerstwie i wspótpracy między Wspólnotami Europejskimi i ich Państwami Członkowskimi a Republika Mołdowy (2004), Dziennik Urzędowy L 181, 24/06/1998 P. 0003-0048, https://eur-lex.europa.eu/legal-content/PL/TXT/HTML/?uri=CELEX:21998A0624(01) $\&$ from $=\mathrm{EN}(14.02 .2020)$.

UN-Vollversammlung fordert Abzug Russlands aus Transnistrien, Zeit, 23.06.2018

UN-Vollversammlung fordert Abzug Russlands aus Transnistrien (2018), "Die Zeit”, 23.06.

Vergessene Konflikte: Das sollten Sie über den „Transnistrien“-Konflikt wissen, Auswärtiges Amt 19.09.2018

Vergessene Konflikte: Das sollten Sie über den "Transnistrien"-Konflikt wissen (2018), Auswärtiges Amt, 19.09, https:/www.auswaertiges-amt.de/de/aussenpolitik/laender/moldau-node/ transnistrien-konflikt/2138338 (28.04.2020).

Zgromadzenie Parlamentarne OBWE uchwaliło rezolucję o wycofaniu rosyjskich sit pokojowych z Naddniestrza (2018), https://studium.uw.edu.pl/zgromadzenie-parlamentarne-obwe-uchwalilo-rezolucje-o-wycofaniu-rosyjskich-sil-pokojowych-z-naddniestrza/ (27.02.2020).

\begin{abstract}
The author indicates in the article that the conflict over Transnistria was not int the field of German close interests. The main task of the German government was to maintain good relations with Russia and to grant it the role of the main mediator in the dispute between Moldova and rebellious Transnistria. On the other hand, Germany, as an EU member, sought to stabilize the region and to bring about democratic and pro-European changes in Moldova. Berlin supported negotiations between the conflicted parties within the OSCE framework albeit aware that they were a sham and would not contribute to the resolution of the conflict. Both the people of Transnistria and Moldova are committed to maintaining the status quo. The absence of physical
\end{abstract}


violence and minor economic and legal tensions have encouraged Western Europe to remain indifferent to Transnistria's problems. In the article the author used the following research methods: historical, descriptive, source analysis and decision making method.

Keywords: Germany, Transnistria, conflict, OSCE, EU

\section{ROLA NIEMIEC W KONFLIKCIE O NADDNIESTRZE}

\section{STRESZCZENIE}

Autor w artykule wskazuje, że konflikt o Naddniestrze nie leżał w polu niemieckich bliskich zainteresowan. Pierwszoplanowym zadaniem niemieckich rządów było utrzymanie dobrych relacji z Rosją i przyznanie jej roli głównego mediatora w sporze pomiędzy Mołdawią i zbuntowanym Naddniestrzem. Z drugiej strony, Niemcom jako członkowi UE zależało na stabilizacji tego regionu, demokratycznych i proeuropejskich przemianach w Mołdawii. W Berlinie wspierano rokowania pomiędzy skonfliktowanymi stronami w ramach OBWE, mając świadomość, że mają one pozorowany charakter i nie przyczynią się do rozwiązania konfliktu. Zarówno mieszkańcom Naddniestrza, jak i Mołdawii zależy na utrzymaniu istniejącego status quo. Brak aktów fizycznej przemocy i drobne spięcia na tle gospodarczym i prawnym sprzyjają zachodniej obojętności wobec problemów Naddniestrza. W artykule autor wykorzystał metody badawcze: metodę historyczną, deskryptywną, analizy źródeł i metodę decyzyjną.

Słowa kluczowe: Niemcy, Naddniestrze, konflikt, OBWE, UE 
